\title{
Brexit, the Conservatives and the General Election
} 2017

Le Brexit, les conservateurs et les élections législatives britanniques de 2017

Dennis Kavanagh

\section{(2) OpenEdition}

\section{Journals}

Electronic version

URL: http://journals.openedition.org/rfcb/2085

DOI: $10.4000 /$ rfcb.2085

ISSN: 2429-4373

Publisher

CRECIB - Centre de recherche et d'études en civilisation britannique

\section{Electronic reference}

Dennis Kavanagh, «Brexit, the Conservatives and the General Election 2017 », Revue Française de Civilisation Britannique [Online], XXIII-2 | 2018, Online since 14 September 2018, connection on 01 May 2019. URL : http://journals.openedition.org/rfcb/2085; DOI : 10.4000/rfcb.2085

This text was automatically generated on 1 May 2019.

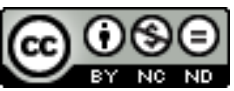

Revue française de civilisation britannique est mis à disposition selon les termes de la licence Creative Commons Attribution - Pas d'Utilisation Commerciale - Pas de Modification 4.0 International. 


\section{Brexit, the Conservatives and the General Election 2017}

Le Brexit, les conservateurs et les élections législatives britanniques de 2017

Dennis Kavanagh

$1 \quad 14 / 09 / 2018$

\section{Introduction}

2 The hung Parliament which resulted from the June 2017 general election is a further instalment in a decade-long period of instability in British politics. It followed the indecisive 2010 general election, the 2014 Scottish referendum, the unexpected 2015 general election result, and the surprise 2016 referendum on the EU. The irony is that the election was not supposed to happen until May 2020, in accordance with the Fixed Term Parliament Act (FTPA). The unexpected election delivered many surprises ${ }^{1}$.

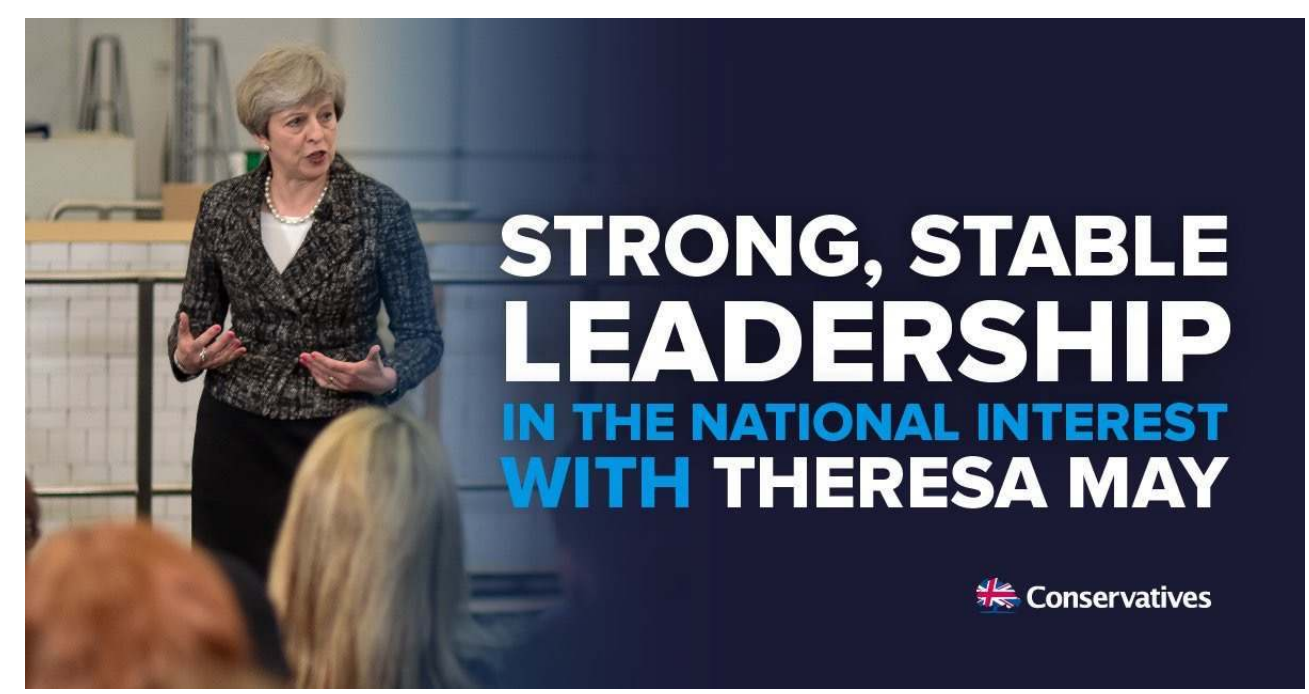

CONSERVATIVe PARTY POSTER 2017 
Yet the 2015 Parliament had already been one of surprises. It did not last the scheduled five years but less than two; Britain unexpectedly voted in a referendum to leave the European Union; the Prime Minister David Cameron resigned after a year in office; and a year later his successor Theresa May called an early general election in search of a bigger majority of seats which, according to the opinion polls, was assured. But instead of delivering a strong and stable government she lost her majority in the Commons, ended up heading a minority government, and a weakened Prime Minister and government embarked on the most important and complex negotiations the UK had entered in living memory.

Another surprise is that the return to two party politics failed to deliver one party majority government, the traditional defence of the first past the post system. However, just one (2015) of the last three general elections has produced a majority for a single party and that was one of only 12 seats and a short-lived Parliament.

The 2017 election was framed by the result of the referendum on Britain's continued membership of the EU which had been held a year earlier. Many of the electoral divisions revealed in the election, particularly of age, education and values, had been foreshadowed in the referendum. But to what extent was it a Brexit election?

\section{Referendum}

David Cameron had promised a referendum the Conservative manifesto for the 2015 general election. He had been pressured to concede one by his MPs and the electoral threat of Ukip. Ukip had campaigned for a referendum on Britain's membership of the EU largely as a device to achieve Britain's departure and was attracting support from the Conservative voters and MPs. Given that all the main parties favoured membership a referendum was the only way to put it on the agenda. Cameron's decision was largely to do with internal party management. The Liberal Democrats, nationalist parties in Scotland and Wales and most of the Labour party were opposed both to holding a referendum and to withdrawal.

7 Having won the general election Cameron decided to call a referendum for June 2016, following his attempt to renegotiate the terms of Britain's membership. He could point to some concessions but he had gained little on the crucial issue of free movement; the Leave campaign's key theme of "Take Back Control" was about sovereignty but essentially about cutting immigration. Cameron had been confident of winning the vote to remain he had won previous referendums on electoral reform in 2011 and independence for Scotland in 2014 - and most final opinion polls suggested his confidence would not be misplaced.

8 In the event the Leave side won by 52 to $48 \%$, a narrow but decisive margin, and Cameron resigned. He was succeeded by Theresa May who soon made it clear that she interpreted the vote as an instruction to leave the customs union, the single market and the jurisdiction of the ECJ. She would deliver Brexit - Britain's departure from the EU. But at that time she had no thoughts of calling an election before 2020 .

9 The referendum had revealed divisions among voters, some of which cut across traditional party votes and political values. Perhaps that was no surprise because it had not been fought on party lines. A NatCen survey, for example, found that social liberals and social traditionalists had different attitudes towards the EU: 66 per cent of 
traditionalists voted to leave, while 18 per cent of liberals did so. Rather than social class the key demographic divides between the two sides were age and education, with the older and the less -educated more likely to vote for leave and the young and those with higher education qualifications to vote for remain. The result also revealed sharp geographic divisions. England and Wales voted to leave, with the prosperous London and south-east of England backing remain, the north backing leave. Northern Ireland and Scotland clearly voted to remain, with no voting area in Scotland backing leave. Britain was evenly divided, as evident in the narrow majority in the vote

The result was a challenge for the two main parties. Two thirds of Labour voters voted remain but according to Chris Hanretty some $70 \%$ of Labour seats voted leave ${ }^{2}$. Many Labour voters in coastal areas, the North and the Midlands were leavers; because they were often elderly and/or lacked educational qualifications they were called the "leftbehinds". Yet other Labour voters, often middle class and university graduates, in university towns, London (the only region in England to vote remain) and major cities were Remainers; they were also more socially liberal, pro-immigration and cosmopolitan in contrast to many of their party's leave voters.

Brexit laid bare the tensions in Labour's electoral coalition and any leader would have problems keeping it intact. In contrast to most of his MPs and party membership the leader Jeremy Corbyn was a Eurosceptic. During the referendum he told an interviewer that he rated his approval of the EU between "seven and seven and a half out of ten"; a member of his core team suggested this was over-generous and it was more like five out of ten at best. And on a smaller but not insignificant scale the Conservatives faced a similar dilemma with a slim remain majority of MPs but a clear leave majority of Conservative members and voters and remainers in its seats in London and the south east. Much of the analysis at the time

\section{The election}

Starting in early 2017 senior colleagues were making the case to May to hold an early election. David Davis, the Brexit minister, warned that the scheduled election date, 2020, would run perilously close to the conclusion of the negotiations for Britain's withdrawal from the EU. Other ministers and advisers pointed to the narrowness of the government's majority (12) which would make passing complex legislation difficult, the lack of a personal mandate for May, the party's clear lead in the opinion polls, and Labour's internal divisions. The case was persuasive. But having served less than a year as PM and with three years of the Parliament to run May needed a compelling reason to dissolve Parliament. Her campaign advisers Lynton Crosby and Mark Textor argued that because voters were uncertain following the referendum, she should call for a mandate to get the best Brexit deal for Britain and end uncertainty. And, given her high personal ratings and massive lead over Corbyn, it should be a highly Presidential campaign built around her rather than the Conservative party ${ }^{3}$. The Crosby Textor plan for a Brexit election meant ditching a campaign which May's Number 10 had been working on. They wanted her to run as a "change" candidate offering radical social and economic reforms to help the "just about managing". She and they had interpreted the referendum vote as a protest against a system that seemed to be working in favour of the well off and against those struggling to make ends meet. On the steps of Downing Street when she had just been 
appointed Prime Minister she had spoken of her determination to tackle what she called "burning injustices" in modern Britain.

Following its election defeat in 2015 Labour had reacted in an unexpected way. The election as leader of Jeremy Corbyn meant that the party ended up with its most left wing leader in the post war period, an outsider who had struggled to get on the ballot and was ranked as a 200-1 outsider in the contest to elect Ed Miliband's successor. In the opinion polls he and his party trailed May and the Conservative by large margins. He struggled to form a shadow cabinet, was opposed by most of his MPs, who at one voted overwhelmingly for him to resign, and was widely expected to lead Labour to a catastrophic election defeat. Labour was more divided than the Conservatives over Brexit, probably another reason why the latter wanted such an election.

\section{A Brexit election?}

After the election some commentators seized on the headline to a British Election Survey's report that it was "A Brexit Election". According to the BES when the voters were asked about the single most important issue facing the country at the time more than third mentioned Brexit (compared to less than 10\% mentioning the NHS and $5 \%$ the economy). It also reported that before the campaign began the Conservatives had already captured a good number of non-Conservative Leave voters, often from Ukip, and Labour had lost many of its Leave voters; it therefore called it a Brexit election ${ }^{4}$. An Ashcroft election day poll of 14, 000 voters ("How did this election result happen?") found that when asked unprompted questions about reasons for their vote Conservatives mentioned Brexit (48\%) and their confidence in May as the best to lead the negotiations. So far so good for the claim that it was a Brexit election.

Yet considering that May called the election ostensibly to give her a Brexit mandate it is striking that the issue figures so little in the campaign and the broadcasters resolutely refused Conservative pressure to cover it as a Brexit election ${ }^{5}$. It was always going to be difficult anyway to frame the election as a Brexit one given that all parties agreed that the referendum result meant that Britain was leaving the $\mathrm{EU}$, although they differed on what kind of Brexit should follow. Liberal Democrats held out the prospect of a second referendum on the outcome of Brexit negotiations but it had little traction with voters. More interesting would been the parties making proposals about what Brexit could lead to and what kind of Britain they envisaged. There was much talk of a soft or a hard Brexit, although the differences probably meant little to most voters. But there was little clarification on such key issues as the numbers and types of immigrants who would be allowed, trade-offs regarding the access to the single market, and role of the European Court of Justice in areas of post-Brexit cooperation. Other matters such as the divorce payment Britain would make to the EU, payments for continued access to the internal market and what kind of Irish border would follow, all prominent in post -election discussions, were hardly touched on. As an educative forum on Brexit and the complex issues it raised the 2017 general election was as bad as the 2016 referendum.

There was always a risk in proposing that the Conservatives campaign on Brexit because May had little concrete to say - or was willing to say - about the trade-offs involved in her plans. Having held her cards close to her chest before the election it was unclear how she could stonewall over the course of a seven -week campaign. Did she have any plans or, if 
she did, was she was fearful that revealing them might spark party and Cabinet divisions? What kind of Brexit did she want that would be acceptable to the EU and keep her party united? In the months following the election and the government had to make decisions the party's divisions between remainers and leavers were exposed.

Corbyn was not much clearer. He had long been a Eurosceptic and had voted against British entry in the first place, against Maastricht and had been lukewarm in his support for the party's remain campaign in the 2016 referendum. Given that the great majority of his MPs and party membership (where his support rested) had backed Britain's continued membership and now favoured a "soft" Brexit he found it prudent to follow a line of "constructive ambiguity". His answer to questions about policy was that he was working for a Brexit that protected jobs and prosperity, trying to avoid offending either side, and not a view that May would disagree with. It was so effective that many Labour voters did not know what the party's policy was. He concentrated on domestic policies, particularly the NHS, housing and education, issues on which the party led the Conservatives. For reasons of internal party management both main party leaders had reasons for not going strong on the issue.

Corbyn's calculation was probably correct. The BES also found that for Labour voters defending the NHS and public services against cuts greatly outweighed Brexit (mentioned by only $8 \%$ ) as the main reason they gave for their vote. Other and more nuanced analysis in Ashcroft's The Lost Majority found that while $29 \%$ (the highest figure) of voters regarded negotiating Britain's exit from the EU as the most important issue facing the country when they were asked what mattered most to "me and my family" the issue fell to third place behind the NHS and the cost of living. Ashcroft comments, "One reason for the Tory miscalculation is that Brexit was just not important enough to enough people"6. The findings may be part of an answer to his question: "If this was the Brexit election, what went wrong?"”.

Some Conservatives regretted that the party failed to spell out how Brexit would improve their everyday lives. The Prime Minister 's Number 10 political strategist and advocate of the "change" agenda, Chris Wilkins later complained about the campaign's focus on the Brexit process, and May just saying "back me":

This was a big negative. Months of research had shown us that talking about Brexit as a process rather than an opportunity would turn people off. What people wanted was for us to explain our policies through the prism of Brexit. In other words, when talking about what you wanted to do with education for example, explain why it was important in the context of Brexit and the kind of country we wanted to be as we emerged from Brexit.

Anti-Brexit Conservatives seized on Labour's capture of a number of Conservative Remain seats in England to make the case for a soft Brexit. Labour's stance was perhaps too ambiguous, too dependent on who the party's spokesperson was, to read much into its stance. But given that the Conservatives were clearly the party for Leave, Labour was probably the default option for Remainers. Corbyn's fence-sitting, motivated more by electoral concerns, paid off for the election.

In view of their Brexit pitch Conservatives might regret that some four million Leave voters in the referendum did not vote in the election; for the most part they were 2015 Ukip and non-voters. Its campaign clearly failed to attract many of those who were outside the political mainstream in 2015 but had been energised a year later by the referendum. On 8 June 14 million Remainers voted but only 13 million Leavers. In 2016 
the figures had been 16 million and 17 million respectively. Peter Kellner argues, on the basis of the large $(52,000)$ YouGov post -election survey, that that had they voted in the same way as other pro-Brexit supporters the Conservatives would have gained an extra 30 seats $^{8}$. But there were also 2015 Labour Leave voters who remained with Labour because other domestic issues mattered to them ${ }^{9}$.

Contrary to much conventional wisdom campaigns clearly can matter - particularly if one party does so badly that it allows the other to perform well. Starting some $20 \%$ ahead in some polls the Conservatives were almost caught up by Labour on polling day. On leadership, Corbyn narrowed his considerable starting deficit against May on the question of being considered a capable Prime Minister. Labour also caught up with the Conservatives on which party could best handle major issues. YouGov showed it overtaking the Conservatives on education and housing to add to its long - established lead on the NHS and narrowing its deficit on managing the economy Voters gave higher marks to Labour's campaign on positivity, honesty, clarity and talking about the issues they cared about. The British Election Study (BES) estimates that 19\% of voters changed their mind during the campaign.

Normally switchers (mostly) cancel each other, as do late-deciders. But in 2017 Labour won more than half of those who changed their minds during the campaign (compared to just $19 \%$ who ended up with the Conservatives) and more than a quarter of those deciding in the last few days ${ }^{10}$ In 2017 the changes in vote intentions had not cancelled out by polling day as Labour manged to recover many of the voters it had lost since 2015, particularly among leave voters.

British elections are becoming more Presidential is so far as the personality of the leader counts for more. It clearly counted in the election victories of Thatcher and Blair and for Cameron over Brown in 2010 and over Miliband in 2015. There was mounting evidence during the seven - week election campaign that May was hopelessly miscast as her party's central message bearer. She avoided a leaders' TV debate with Corbyn, robotically repeated her lines in interviews, and was filmed having meetings with supporting small groups. Meanwhile Corbyn was filmed nightly address packed rallies of enthusiastic supporters. If effective campaigns are about the candidate making an emotional connection, appearing authentic and empathetic, and providing good photo opportunities for cameras there was only one winner in 2017.

\section{Result}

The Conservative campaign has been widely regarded as a failure largely because it surrendered its majority. In part the negative assessment has been driven by the high expectations at the outset. Yet the party ended with 55 more seats than Labour, 43.5\% was its highest vote share since 1983 and at each general election since 1997 it has increased its share of the vote. It achieved its highest share in Wales in a century and reversed a long period of decline in Scotland., ran ahead of Labour for first time since 1959. Its gains in the North and Scotland and among the working class made it more of a national party, something Cameron's modernisation project had aspired to. The increase in its vote share of nearly $6 \%$ was reasonably expected to deliver a majority of seats for the Conservatives. A similar vote share had gained Mrs Thatcher a landslide victory in 1983. What was not anticipated and upset the calculations was that Labour's vote would 
increase from 2015 by as much as $9.8 \%$, resulting in a $2 \%$ swing in its favour. As May admitted after the election: "We didn't see this coming"

What emerges from survey and geographical analysis is the extent to which the votes of the 2016 referendum cast a shadow over the election, loosening the party ties of both former Conservative and Labour voters. A significant minority of voters shifted to align their 2017 party vote with their 2016 referendum vote and in the process sharpened the age and education differences between the parties. According to YouGov, 22\% of Labour/ Leave voters who voted in 2017 switched to the Conservatives while 17\% of Conservative/ Remain voters switched to Labour. But the turnout was higher (88\%) among the remainers than among the leavers $(79 \%)^{11}$. The Conservatives may have underestimated the softness of its remainer votes and as John Curtice cautioned: "In appealing to the Brexiters, May seems to have forgotten that she needed to carry with her the half of the country that voted remain"12. He might have added that a good number of them were Conservatives, often young, well-educated and socially liberal, and who were prepared, because of Brexit, to defect to Labour.

Work by Jennings and Stoker places these social and political trends in a longer-term perspective. They argue that the 2015 election, the referendum vote and the 2017 election are the outcomes of a gradual bifurcation of English politics, between metropolitan and cosmopolitan areas of economic growth whose inhabitants are comfortable with diversity and are outward looking, versus backwater areas, often provincial and coastal parts, whose inhabitants are uneasy about globalisation, technical progress, immigration and Europe $^{13}$. The latter have been called the left behinds but, given that a good number are middle class, although often elderly, an alternative title might be the left outs. The Conservatives ended with 313 seats, 13 down on 2015. Labour ended with 262, an increase of 30 , and gained 28 from the Conservatives. The Conservatives gained more than half of the 2015 Ukip vote and increased their vote share in leave voting seats. Labour retained many of its leave voting supporters but also did well in remain seats, capturing a number of such Conservative seats ${ }^{14}$. The insurgent parties of 2015 suffered a major reverse; Ukip's $12.9 \%$ of the 2015 vote shrunk to less than 2\% (many Ukippers decided not to vote or did not have a candidate to support) and in Scotland the SNP lost a third of its vote and its MPs. The most striking finding of the election is that age has replaced social class as the main divide between Labour and Conservative when it comes to elections, another referendum echo. As the over-55s swung to the Conservatives, the under-44 swung to Labour, producing the biggest age gap since polling records were compiled. You Gov claimed that 47 was the age cut-off between the parties on $8^{\text {th }}$ June. The cut-off had been 34 at the start.

31 The relationship between social class and vote weakened further as Labour's share of the middle class and Conservative share of the working class reached their highest levels since 1979 when Mrs Thatcher was first elected. Although the Conservatives had an 8\% lead among $\mathrm{ABC} 1 \mathrm{~s}$, Labour increased its share among this group by $12 \%$. And while Labour led by $4 \%$ among C2DE voters the Conservatives increased their share by $12 \%$. Both parties are becoming more cross-class in their voting support. Long gone are the days when it could be said that British politics was based on social class and that "all else is embellishment and detail". 
In recent elections Britain has moved to a multi-party system, with Labour and Conservative together averaging less than $70 \%$ of the vote. In 2017, however, their combined share rose to over $82 \%$ and $87.5 \%$ in England. The reassertion of two party dominance is confined to England and Wales - in Scotland the SNP still has the most seats. But the system has been restored with a difference. No longer are the parties' support buttressed by strong levels of class and partisan alignment, features which gave then a dependable core support, election-after-election. What has emerged in 2017 is an ersatz form of two-party politics - with a more middle-class, socially liberal and younger Labour and a more working class and more conservative socially and culturally Tory party. Support for both parties now rests on low levels of partisan identity - and one that could well collapse just as easily as it seemed to arrive. The new, potentially uneasy, coalitions were foreshadowed in the referendum and pose a challenge to the two main parties.

\section{Conclusion}

An election called to provide strong government and reduce uncertainly delivered the opposite on both counts. How likely is it that May's government, in a minority and dependent on the DUP's ten MPs, will survive by - election reverses, defections and rebellions until the next general election, scheduled (according to the Fixed Term Parliament Act) for June 2022? In 1992 John Major's initial majority of 21 seats had disappeared by 1996 . The hand to mouth existence of Labour minority governments in 1950,1974 and 1976-79 is hardly encouraging. Conditions which usually help sustain a minority government include: the good - will it has if it is a first- time government; its MPs believe that they owe their election to the leader's popularity - a "coat-tails effect"; the party is united on key issues; and the Prime Minister can credibly threaten opposition parties with an election in which they are likely to lose ground. May's government meets none of these favourable conditions.

In the days following the election a jubilant Labour team eagerly looked forward to another contest; momentum was with the party. But if the Conservatives need a swing of $0.5 \%$ to gain a majority of seats next time Labour ${ }^{15}$ needs one of nearly $5 \%$ to do so. And it is unlikely to be a case of "one more heave". Compared to the seats they won in 2017, the seats they need to capture next time contain fewer voters who are young, graduates, and black and ethnic minorities. Labour's optimism needs to qualified.

An unfortunate legacy of Brexit is how the issue has coarsened political debate. Remain supporting MPs have been attacked as "Remoaners" and leave supporting newspapers have attacked MPs hostile to Brexit as "saboteurs" and "traitors" and questioned the integrity of sections of the civil service, judiciary, and Electoral Commission. In turn some remainers have implied that leavers' demands for cuts to immigration has a racial undertone and the Liberal Democrat leader Vince Cable has claimed that the leave vote was largely by the elderly who were "driven by nostalgia" and longed for a world where "faces were white".

The European project (from the EC to the EU) has been a destabilising force in British politics for nearly four decades. Labour's call for withdrawal and a referendum split the party and led to the creation of the SDP in 1981. Since then it has divided the Conservative party which has moved in a steadily Eurosceptic direction. Divisions over the issue undermined the final stages of the premierships of Thatcher, Major and 
Cameron. Dissatisfaction with the EU fuelled the rise of Britain's largest insurgent party, Ukip, which gained 3.8 million votes in 2015 and forced the referendum. Even as Britain negotiates its divorce the potential capacity for the European issue to cause strife is unabated.

\section{BIBLIOGRAPHY}

Ashcroft, M., The Lost Majority (London, Biteback, 2017).

Cowley, P \& Kavanagh, D. (dir.), The British General Election of 2017 (London, Palgrave, 2018).

Curtice J., "Labour's strategy delivered - up to a point", The Times, $9^{\text {th }}$ June 2017.

Curtice J., "Why did Brexit not work for the Conservatives?", blog, 24 $4^{\text {th }}$ October 2017.

Cushion, S. \& Beckett, C., "Campaign Coverage and Editorial Judgements: Broadcasting” in Cowley, P. \& Kavanagh D. (dir.), The British General Election of 2017 (London, Palgrave, 2018).

Evans, G. \& Menon, A., Brexit and British Politics (Cambridge, Polity Press, 2017).

Fieldhouse, E. \& Prosser, C., “General Election 2017: Brexit dominated voters' thoughts”, BBC, $1^{\text {st }}$ August 2017, http://www.bbc.co.uk/news/uk-politics-40630242.

Hanretty, C., "Areal Interpolation and the UK's referendum on EU membership”, Journal of Elections, Public Opinion and Parties, 2017, https:doi.org/10.1080/17457289.2017.1287081.

Heath, O. \& Goodwin, M., "The 2017 general election. Brexit and the return to two-party politics. An Aggregate-level analysis of the results", Political Quarterly, 88, 2017, pp. 345-58.

Jennings, W. \& Stoker, G., "The Bifurcation of Politics; The Two Englands”, Political_Quarterly, 87, 2016, pp. 372-382.

Jennings, W. \& Stoker, G., "Tilting Towards the Cosmopolitan Axis? Political Change in England and the 2017 General Election", Political Quarterly, 88, 2016, pp. 359-379.

Kellner, P., "Why did so many voters switch parties between 2015 and 2017?", New_Statesman, 29 ${ }^{\text {th }}$ September 2017.

Ross, T. \& McTague, T., Betting the House (London, Biteback, 2017).

Shipman, T., Fallout (London, William Collins, 2017).

Surridge, P., "Marginal Gains" in Perryman, M. (dir.) The Corbyn Effect (London, Lawrence \& Wishart, 2017).

\section{NOTES}

1. Studies of the election include: SHIPMAN, T., Fallout (2017), London: William Collins, ROSS, T. and McTAGUE, T., Betting the House (2017), London: Biteback, and COWLEY, P. and KAVANAGH, D., The British General Election of 2017 (2018), London: Palgrave. 
2. HANRETTY, C., "Areal Interpolation and the UK's referendum on EU membership", Journal of Elections, Public Opinion and Parties, 2017, https:doi.org/10.1080/17457289.2017.1287081, concentrated on the many leave voting Labour seats and the remain supporting Labour MPs and neglected the Conservative problem.

3. See COWLEY and KAVANAGH, op. cit, chapter 1.

4. FIELDHOUSE, E. and PROSSER, C., "General Election 2017: Brexit dominated voters thoughts". BBC. 1 August, 2017. http://www.bbc.co.uk/news/uk-politics-40630242

5. See CUSHION, S. and BECKETT, C., "Campaign Coverage and Editorial Judgements: Broadcasting" in COWLEY and KAVANAGH, op. cit.

6. ASHCROFT, M., The Lost Majority (2017), London: Biteback, p.58.

7. Ibid., p. 58-9.

8. KELLNER, P., "Why did so many voters switch parties between 2015 and 2017?" New Statesman, 29 September 2017.

9. ASHCROFT, op. cit., p. 58

10. FIELDHOUSE, E. and PROSSER, C., op.cit., and ASHCROFT, op. cit., pp. 41-2.

11. KELLNER, op. cit.

12. CURTICE, J., "Labour's strategy delivered - up to a point", The Times 9 June 2017 and his blog, "Why did Brexit not work for the Conservatives?" 24 Oct 2017.

13. JENNINGS, W. and STOKER, G., "The Bifurcation of Politics; The Two Englands", Political Quarterly, 87, 2016, pp. 372-382, and their "Tilting Towards the Cosmopolitan Axis? Political Change in England and the 2017 General Election", Political Quarterly, 88, 2017, pp. 359-379. Also see EVANS, G. and MENON, A., Brexit and British Politics (2017), Cambridge: Polity Press.

14. HEATH, O. and GOODWIN, M., "The 2017 general election. Brexit and the return to two-party politics. An Aggregate-level analysis of the results", Political Quarterly 88 (2017) pp. 345-58

15. SURRIDGE, P., "Marginal Gains" in PERRYMAN, M. (ed.), The Corbyn Effect (2017), London: Lawrence \& Wishart.

\section{ABSTRACTS}

Theresa May called a general election in 2017, hoping to increase her Parliamentary majority and to strengthen her authority in negotiating Britain's withdrawal from the EU. Although her Conservative party ended up as the largest party she lost her majority in the House of Commons. The 2016 referendum, which voted for Britain to leave foreshadowed new patterns of political alignment and these could be seen in the general election

Theresa May déclencha une élection en 2017 afin d'augmenter sa majorité parlementaire et renforcer son autorité pour mener à bien les négociations de sortie de l'UE du Royaume-Uni. Or, bien que son parti en soit ressorti vainqueur, elle perdit sa majorité. Le référendum de 2016 
résultant sur le processus du Brexit préfigurait de nouveaux alignements politiques qui caractériseraient les élections législatives britanniques de 2017.

INDEX

Mots-clés: Brexit, élections législatives britanniques, Theresa May, référendum de juin 2016, Jeremy Corbyn

Keywords: Brexit, Elections, Theresa May, EU Referendum, Jeremy Corbyn.

\section{AUTHOR}

DENNIS KAVANAGH

Emeritus professor, University of Liverpool 